\title{
Pengaruh Strategi Promosi Terhadap Keputusan Pembelian Motor Yamaha Mio Pada PT. Hasjrat Abadi Tobelo
}

\author{
Remart Ricards Duan \\ Johnny A.F. Kalangi \\ Olivia Walangitan \\ Jurusan Ilmu Administrasi Program Studi Administrasi Bisnis \\ Fakultas Ilmu Sosial dan Ilmu Politik Universitas Sam Ratulangi Manado \\ ricardsduan@gmail.com
}

\begin{abstract}
The purpose of this study was to determine the effect of promotion strategy on purchasing decisions of Yamaha Mio motors at PT Hasjrat Abadi Tobelo. PT. Hasjrat Abadi Tobelo launched the Matic type Mio Z, Mio M3 CW and Mio S types which are now popular in 2018. In 2017 Yamaha Mio sales were 428 units of motorcycles while in 2018 Yamaha Mio sales were 434 units of motorcycles, which means that in 2018 there was an increase in sales of Yamaha Mio. This research is a kind of quantitative descriptive research, using a correlation approach and simple regression, to see the relationship between variables and measure the magnitude of the influence that occurs in these variables. In the descriptive section of respondent's characteristics it can be seen that the respondents were the most female, namely 58.9\%, respondents aged 20-30 years as much as $42.3 \%$, and based on the latest education undergraduate students and respondents with civil servants (PNS) as much as 47\%, is the respondent whose number is the most or dominant. Based on the results of the SPSS data the results of the determination coefficient or $R$ Square (R2) are 0.379. From the equation above, it can be seen that if there are no independent variables that influence, promotion strategy 9,509 and every 1\% increase in the promotion level, then the purchasing decision will increase by 0,791\%. the results of simple linear regression analysis in the table above can be seen the results of calculations between promotional strategy variables on purchasing decisions can be arranged with the formula $Y=a$ $+b x$ which means $Y=9.509+0.791 X$. From the results above, the researcher gives the conclusion that promotional strategies are variables that influence purchasing decisions. This means that the higher the promotion strategy offered by Yamaha Mio, the higher the level of purchasing decisions.
\end{abstract}

Keywords: Promotion Strategy, Purchasing Decision

\section{Pendahuluan}

Perkembangan jaman yang semakin maju seperti sekarang ini banyak sekali terdapat merek-merek sepeda motor yang di tawarkan kepada konsumen seperti merek Yamaha, Honda, Suzuki, Kawasaki, dan lain sebagainya. Masing-masing sepeda motor tersebut berusaha untuk membuat produknya lebih unggul dibandingkan dengan merek lain, maka kegiatan pemasaran yang baik dan tetaplah yang memegang peranan yang penting dalam menunjang kelangsungan usaha dan perkembangan suatu perusahaan, dengan kata lain pihak produsen harus mampu merebut hati konsumen terhadap hasil suatu 
produksi yang dijual dan berupaya untuk memuaskan konsumennya.

Berikut ini merupakan pengertian promosi menurut beberapa pendapat para ahli diantaranya yaitu menurut Kotler dan Armstrong (2012) "promotion means activities that communicate the merits of the product and persuade target customers to buy it". Artinya promosi merupakan kegiatan yang mengkomunikasikan manfaat dari sebuah produk dan membujuk target konsumen untuk membeli produk tersebut.

Pada umumnya perusahaan PT. Hasjrat Abadi Tobelo adalah perusahaan dealer resmi sepeda motor Yamaha yang melayani kebutuhan masyarakat dibidang transportasi melalui pembelian secara tunai maupun kredit dan terus berusaha memperkuat posisi dari pesaing-pesaing. Namun yang kita ketahui juga setiap perusahaan pasti mengalami masalah atau kendala-kendala yaitu seorang manajemen tidak memprioritaskan kegiatan promosi pada produk Yamaha Mio dalam mempromosikannya,

Salah satu kendaraan pribadi yang paling banyak digunakan masyarakat Indonesia khususnya masyarakat TOBELO (Halmahera Utara) adalah sepeda motor, karna sepeda motor memliki banyak manfaat dan keunggulan dari pada mobil seperti hemat bahan bakar atau bensin, lancar pada saat terjebak macet, biaya perawatan yang rendah, harga beli yang murah dan terjangkau bagi kalangan masyarakat. Hal ini membuat produsen motor semakin berinovasi dengan produknya sehingga pesaing antara merek yamaha semakin tajam untuk melawan merek honda untuk merebut hati konsumen. Namun PT. Hasjrat Abadi Tobelo mengalami peningkatan minat konsumen terhadap motor Yamaha Mio. Untuk memuaskan konsumennya, PT. Hasjrat Abadi Tobelo meluncurkan sepeda motor yang jenis Matic yang bertipe Mio Z, Mio M3 CW dan Mio S yang sekarang lagi populer pada tahun 2018. Pada Tahun 2017 penjualan Yamaha Mio sebesar 428 unit motor sedangkan pada tahun 2018 penjualan yamaha mio sebesar 434 unit motor.

Perusahaan ketat terutama terjadi pada Yamaha dan Honda untuk memperebut posisi puncak. Pertumbuhan penjualan motor Yamaha tidak mengalami penurunan minat konsumen karna Yamaha mampu berpengaruh signifikan unggulnya produk yamaha sehingga menimbulkan keputusan pembelian. Berdasarkan latar belakang masalah diatas maka peneliti tertarik mengambil judul "Pengaruh Strategi Promosi terhadap Keputusan Pembelian Motor Yamaha Mio pada PT. Hasjrat Abadi Tobelo". 


\section{Kajian Teori}

\section{Manajemen Pemasaran}

Setiap produsen selalu berusaha melalui produk yang dihasilkan dapat terjual atau dibeli oleh konsumen akhir dengan tingkat harga yang memberikan keuntungan perusahaan jangka panjang. Melalui produk yang dapat dijualnya, perusahaan dapat menjamin kehidupannya atau menjaga kestabilan usahanya dan berkembang. Pengertian manajemen pemasaran menurut Sofjan Assauri (2013). Adalah manajemen pemasaran merupakan kegiatan penganalisisan, perencanaan, pelaksanaan, dan pengendalian programprogram yang dibuat untuk membentuk, membangun, dan memelihara keuntungan dari pertukaran melalui sasaran pasar guna mencapai tujuan organisasi (perusahaan) dalam jangka panjang. Pemasaran merupakan suatu kegiatan bisnis yang dilakukan oleh individu maupun kelompok untuk memenuhi kebutuhan, keinginan konsumen dan masyarakat. Pemasaran melibatkan semua orang dalam perusahaan yang bekerja untuk menciptakan dan mempertahankan pelanggan yang sudah ada, orientasi ini semakin didasari sebagai kunci peningkatan manajemen pemasaran untuk membantu perusahaan dalam mencapai tujuan.

\section{Strategi Pemasaran}

Strategi pemasaran adalah suatu strategi yang dilakukan oleh suatu perusahaan untuk meningkatkan penjualan atas produk dan pasar yang telah tersedia melalui usaha-usaha pemasaran yang lebih agresif. Menurut Tjiptono (2012). Mendefinisikan strategi pemasaran sebagai berikut: Strategi pemasaran adalah alat fundamental yang direncanakan untuk mencapai tujuan perusahaan dengan mengembangkan keunggulan bersaing yang berkesinambungan melalui pasar yang dimasuki dan program pemasaran yang digunakan untuk melayani pasar sasaran tersebut. Selain itu Kotler dan Keller terjemahan Bob Sabran (2012). Mendefinisikan bahwa strategi pemasaran adalah logika pemasaran dimana unit bisnis berharap untuk menciptakan nilai dan mendapatkan keuntungan dari hubungannya dengan konsumen. Berdasarkan beberapa pengertian diatas maka dapat disimpulkan bahwa strategi pemasaran merupakan alat yang direncanakan oleh perusahaan untuk mencapai tujuan perusahaan dengan menggunakan serangkaian kegiatan pemasaran dengan membangun kombinasi elemen dari bauran pemasaran. 


\section{Tujuan Strategi Pemasaran}

Tujuan pemasaran adalah membuat penjualan tidak diperlakukan lagi penjualan dan iklan hanyalah bagian dari bauran pemasaran yang lebih besar seperangkat sarana pemasaran yang bekerja semua untuk memuaskan kebutuhan pelanggan dan menciptakan hubungan dengan pelanggan. Menurut Kotler dan keller (2016). Menyatakan marketing is the activity, set of institutions, and processes for creating, communication, delivering, and exchanging offerings that for customers, clients, partners, and society at large. Definisi tersebut mendefinisikan bahwa pemasaran adalah kegiatan mengatur Lembaga, dan proses untuk menciptakan, mengkomunikasikan, menyampaikan, dan bertukar penawaran yang nilai bagi pelanggan, klien, mitra, dan masyarakat pada umumnya. Tujuan perusahaan akan mencapai apabila dalam menjalankan usahanya dijalani bersamaan dengan pelaksanaan pemasaran yang baik. Karena dengan kita melakukan dan melaksanakan manajemen pemasaran dengan baik maka kita akan dapat memaksimalkan potensi yang dimiliki perusahaan sehingga dapat mencapai tujuan perusahaan tersebut.

\section{Strategi Promosi}

Berikut ini merupakan pengertian promosi menurut beberapa pendapat para ahli diantaranya pengertian promosi menurut Kotler dan Armstrong (2012) "Promotion means activities that communicate the merits of the product and persuade target customers to buy it". Artinya promosi merupakan kegiatan yang mengkomunikasikan manfaat dari sebuah produk dan membujuk target konsumen untuk membeli produk tersebut.

Menurut Agus Hermawan (2013) Mengemukakan bahwa : "Promosi adalah salah satu komponen prioritas dari kegiatan pemasaran yang memberitahukan kepada konsumen bahwa perusahaan meluncurkan produk baru yang menggoda konsumen untuk melakukan kegiatan pembelian".

Berdasarkan pengertian di atas peneliti dapat disimpulkan bahwa promosi merupakan penting dalam memasarkan suatu produk sehingga konsumen akan tertarik dan melakukan pembelian terhadap produk tersebut, sehingga suatu promosi perlu dirancang semenarik mungkin dan informasi yang disampaikan dapat di mengerti dengan mudah oleh masyarakat.

\section{Tujuan Strategi Promosi}

Tujuan dari promosi penjualan sangat beraneka ragam yakni merangsang permintaan, meningkatkan hasrat 
konsumen untuk mencoba produk tersebut.

Meningkatkan pembelian konsumen untuk membeli lebih banyak serta meminimalkan perilaku berganti-ganti merek, atau mendorong konsumen untuk mencoba pembelian produk baru.

\section{Keputusan Pembelian}

Menurut Kotler dan Armstrong (2016). Mendefinisikan keputusan pembelian sebagai berikut: Consumer behavior is the study of how individual, groups, and organizations select, buy, use, and dispose of goods, services, ideas, or experiences to satisfy their needs and wants. Yang artinya keputusan pembelian merupakan bagian dari perilaku konsumen yaitu studi tentang bagaimana individu, kelompok, dan organisasi memilih, menggunakan, dan bagaimana barang, jasa, ide atau pengalaman untuk memuaskan kebutuhan dan keinginan konsumen. Keputusan adalah suatu reaksi terhadap beberapa solusi alternative yang dilakukan secara sadar dengan menganalisis kemungkinan-kemungkinan dari alternative tersebut bersama dengan konsekuensinya.

Berdasarkan pengertian diatas dapat diartikan bahwa keputusan pembelian merupakan suatu motif yang timbul dari dalam diri seseorang untuk membeli suatu produk barang atau jasa untuk konsumen pribadi Hubungan Promosi Dengan
Keputusan Pembelian Dalam hal ini hubungan promosi penjualan terhadap keputusan pembeli sangat Erat. Ini dikarenakan promosi penjualan menjadi program yang menentu-kan dalam pembelian konsumen terhadap produk atau jasa. Karna melalui pelaksanaan promosi penjualan perusahaan akan dapat memberikan informasi yang nyata dan langsung kepada calon konsumennya.

Menurut Fandy Tjiptono (2014) Keputusan pembelian adalah sebuah proses dimana konsumen mengenal masalahnya, mencari informasi mengenai produk atau merek tertentu dan mengevaluasi seberapa baik masing-masing alternatif tersebut dapat memecahkan masalah, yang kemudian mengarah pada keputusan pembelian.

\section{Penelitian Terdahulu}

J. J Lenzum, J.D.D. Masie, D.Andre (2014) Melakukan penelitian tentang" Pengaruh kualitas produk, harga, dan promosi terhadap kepuasan pelanggan kartu prabayar telkomsel". Tujuan penelitian ini adalah untuk mengetahui pengaruh kualitas produk, harga, dan promosi terhadap kepuasaan pelanggan pengguna kartu prabayar kelurahan winangun 1. Populasi penelitian ini adalah pelanggan penguna kartu prabayar Telkom. Teknik sampling yang digunakan accidental sampling 
dengan jumlah sampel 95 orang. Metode penelitian asosiatif dengan menggunakan metode analisis regresi linear sederhana.

Moningir, Mandey dan Ogi (2016) Melakukan penelitian tentang penerapan strategi pemasaran untuk mencapai keunggulan bersaing (Studi kasus pada Multimart Ranotana Manado) Tujuan penelitian ini untuk mengetahui strategi apa yang digunakan perusahaan untuk mencapai keunggulan bersaing khususnya di kota Manado, jenis penelitian yang digunakan adalah deskriptif kualitatif. Hasil penelitian menunjukan strategi pemasaran yang digunakan Multimart dapat meningkatkan volume penjualan dengan tetap menjunjung tinggi semboyan "Kami memang beda" serta dengan memberikan kartu member.

I. G. Yulia purnama sari (2015) Melakukan penelitian tentang pengaruh kualitas produk dan harga terhadap kepuasaan konsumen produk M2 Fashion Online. (1) pengaruh kualitas produk terhadap kepuasaan konsumen. pengaruh harga produk terhadap kepuasaan konsumen. (3) pengaruh kualitas produk dan harga terhadap kepuasaan konsumen produk M2 Fashion Online. Jenis penelitian ini menggunakan penelitian kuantitatif. Jumlah sampel dalam penelitian sebanyak 100 orang responden. Data dikumpul dengan menggunakan metode dokumentasi dan kuesioner. Dianalisis menggunakan analisis regresi linear berganda dengan bantuan program SPSS for Windows 16.0.

\section{Metode Penelitian}

Jenis penelitian ini merupakan jenis penelitian deskriptif Kuantitatif, dengan menggunakan pendekatan korelasi dan regresi sederhana, untuk melihat hubungan antara variabel serta mengukur besarnya pengaruh yang terjadi pada variabel tersebut. Data yang dicari dari penelitian ini adalah data penjualan motor Yamaha Mio dari perusahaan dan koesioner yang dibagikan kepada konsumen yang diperoleh berdasarkan pembagian kuesioner, wawancara, dan observasi. Tempat penelitian ini dilakukan pada PT. Hasjrat Abadi Tobelo dengan waktu pelaksanaan bulan Maret 2019 sampai selesai. Populasi dalam penelitian ini adalah konsumen/ pembeli sepeda motor Yamaha Mio pada PT. Hasjrat Abadi Tobelo yang berjumlah 862 orang konsumen, untuk 2 tahun terakhir yaitu tahun 2017-2018. Menentukan jumlah sampel Menurut Sugiyono (2016) dalam penelitian ini sampel yang akan diambil oleh peneliti dan diterapkan adalah sebanyak maksimal 85 konsumen.

Dalam penelitian ini untuk pengukuran masing-masing variabel dengan menggunakan skala Likert. Skala 
Likert yaitu pertanyaan-pertanyaan yang memberikan lima alternative jawaban.

\section{Hasil Penelitian}

\section{Uji Validitas}

Uji Validitas menunjukan sejauh mana suatu alat pengukur dapat mengukur apa yang ingin diukur. Jika menggunakan kuesioner sebagai alat dalam pengumpulan data, kuesioner yang disusun harus mengukur apa yang di ukurnya. Instrument yang valid dapat diartikan bahwa alat ukur yang digunakan dalam penelitian untuk mendapatkan data adalah valid.

Adapun dasar pengambilan keputusan dari uji validitas ini yaitu jika nilai $r$ hitung $>\mathrm{r}$ tabel maka angket tersebut dinyatakan valid. Sebaliknya jika nilai $r$ hitung $<r$ tabel maka item pernyataan tersebut dinyatakan tidak valid.

\section{Uji Reliabilitas}

Uji Reliabilitas adalah sejauh mana hasil pengukuran dengan menggunakan objek yang sama akan menghasilkan data yang sama (Sugiyono 2012). Pengujian Reliabilitas instrumen dilakukan untuk menunjukan sejauh mana hasil pengukuran dapat dipercaya. Instrument yang reliabel adalah instrumen yang bisa dilakukan beberapa kali untuk mengukur objek yang sama akan hasilkan data yang sama. Reliabilitas variabel ditentukan berdasarkan nilai alpha cronbach, apabila nilai alpha cronbach lebih besar dari 0,6 maka dikatakan variabel tersebut reliabel atau dapat diandalkan.

\section{Analisis Regresi Sederhana}

Analisis regresi sederhana adalah hubungan secara linear antara satu variabel independen (x) dengan variabel dependen (y). Analisis ini untuk mengetahui arah hubungan antara variabel independent dan variabel dependen apakah positif atau negatif dan untuk memprediksi nilai dari variabel dependen apabila nilai variabel independen mengalami kenaikan atau penurunan.

\section{Uji Hipotesis (Uji t)}

Uji $\mathrm{t}$ digunakan untuk mengetahui apakah variabel bebas memiliki pengaruh signifikasi terhadap variabel terikat. Untuk menguji variabel $\mathrm{x}$ memiliki pengaruh signifikasi terhadap variabel y, hipotesisnya adalah $\mathrm{H}=$ tidak ada korelasi dan $\mathrm{A}$ ada korelasi.

Hasil Penelitian diketahui nilai signifikasi sebesar 0,000 lebih kecil dari probabilitas 0,05 , sehingga dapat disimpulkan terdapat pengaruh positif antara strategi promosi terhadap keputusan pembelian Motor Yamaha Mio pada PT. Hasjrat Abadi Tobelo. 


\section{Koefisien Korelasi}

Koefisien korelasi dapat digunakan untuk mengetahui hubungan variabel bebas (x) terhadap variabel terikat (y). Yang menjadi dasar pengambilan keputusan pada analisis koefisien korelasi adalah, jika nilai signifikasi $<0,05$ maka variabel $\mathrm{x}$ dan $\mathrm{y}$ memiliki korelasi tetapi jika nilai signifikasi > 0,05 maka tidak berkorelasi. Untuk mengetahui seberapa kuat korelasi antara variabel $\mathrm{x}$ dan $\mathrm{y}$.

Hasil koefisien determinasi atau $\mathrm{R}$ Square (R2) adalah menunjukan bahwa keputusan pembelian motor Yamaha Mio PT. Hasjrat Abadi Tobelo dipengaruhi oleh variabel strategi promosi.

\section{Pembahasan}

Pada bagian deskriptif karakterisik dapat dilihat bahwa responden berjenis kelamin perempuan paling banyak dan berusia 20-30 tahun. Berdasarkan pendidikan terakhir sarjana S1 dan pekerjaan responden adalah pegawai negri sipil. Pada Hasil analisis dengan menggunakan aplikasi SPSS versi 21, Hasil tabulasi reliabilitas berdasarkan rumus alpa cronbach menunjukan bahwa variabel strategi promosi dan keputusan pembelian dinyatakan Reliabel.

Dari hasil uji regresi sederhana yaitu mengandung arti bahwa setiap penambahan
$1 \%$ tingkat strategi promosi maka keputusan pembelian akan meningkat.

Berdasarkan hasil koefisien korelasi dan analisis korelasi menunjukan bahwa adanya variabel strategi promosi dengan keputusan pembelian dimana nilai Sig.

\section{Kesimpulan}

Berdasarkan hasil penelitian dan pembahasan maka dapat disimpulkan sebagai berikut:

Strategi promosi merupakan variabel yang berpengaruh terhadap keputusan pembelian. Hal ini mengandung makna bahwa semakin tinggi strategi promosi yang di tawarkan oleh Yamaha Mio, Maka semakin tinggi pula tingkat keputusan pembelian.

Berdasarkan pengujian tersebut maka strategi promosi dapat digunakan untuk meramalkan keputusan pembelian, yang artinya apabila strategi promosi dapat ditingkatkan pada besaran tertentu, maka dapat dipastikan tingkat keputusan pembelian mengalami peningkatan.

\section{Saran}

PT. Hasjrat Abadi Tobelo perlu mempertahankan terus produk, harga, dan strategi promosi dalam rangka meningkatkan keputusan pembelian sepeda motor Yamaha Mio agar penjualan meningkat lebih maksimal. Bagi para 
peneliti yang berminat untuk mengkaji dan meneliti ulang penelitian ini. Disarankan lebih memperdalam dan memperluas variabel, yaitu Harga (Price), kesan kualitas (Perceived), kemampuan layanan (Serviceability) yang memiliki pengaruh sebesar $62,1 \%$ dalam penelitian untuk membuktikan hasil penelitian pada PT. Hasjrat Abadi Tobelo.

\section{Daftar Pustaka}

Assauri, Sofjan. 2013. Manajemen Pemasaran. Jakart : Rajawali Pers

Fandy Tjiptono. 2012. Strategi Pemasaran, ed. 3, Yogyakarta, Andi.

Kotler dan Keller, 2012. Manajemen Pemasaran Edisi Ketigabelas Jilid 1 dan 2 Dialih-bahasakan Oleh Bob Sabran, Jakarta: Erlangga.

Kotler, Philip, dan Gary Armstrong 2012. Prinsip-prinsip Pemasaran. Edisi 13. Jilid 1. Erlangga : Jakarta

Moningir, Mandey dan Ogi 2016. Strategi Pemasaran Untuk Mencapai Keunggulan Bersaing (Studi kasus pada Multimart Ranotana Manado). Jurnal EMBA Vol. 6 No.2 April 2018, Hal. 968-977.

Sugiyono. 2016. Metode Penelitian Kuantitatif, Kualitatif dan $R \& D$. Bandung: PT Alfa 